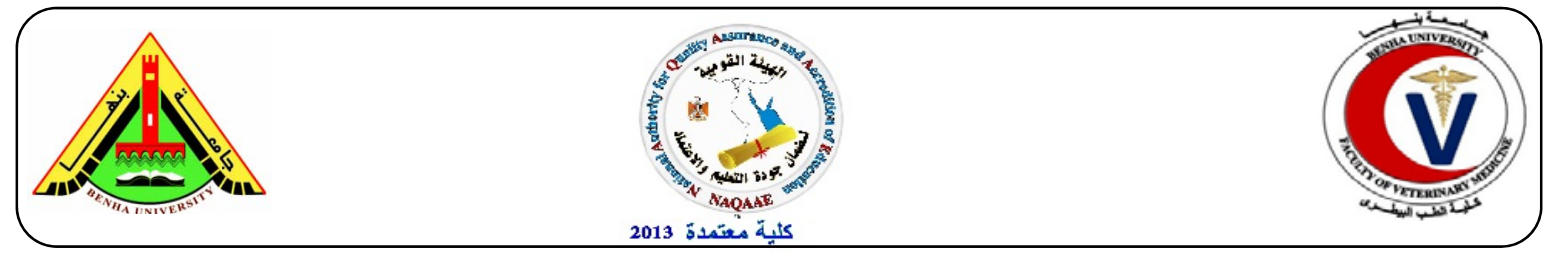

\title{
Evaluation of combined vaccines against bovine brucellosis
}

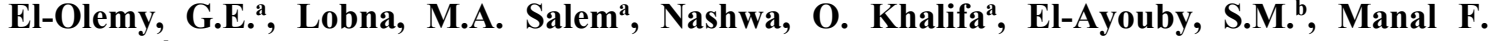 \\ Mohamed $^{\text {b }}$ \\ ${ }^{a}$ Department of Zoonosis, Faculty of Veterinary Medicine, Benha University, ${ }^{b}$ Veterinary Serum and \\ Vaccine Research Institute, Sera and Antigens Department, Abbasia, Cairo
}

\begin{abstract}
A B S T R A C T
Ten female local breed cows proved to be brucella free (six of them were pregnant, parturated and lactate during the experiment time) were subdivided into two subgroups, the first one vaccinated with combination of HS and OMPs subunit vaccines combined with conjunctival vaccination with Br. abortus strain 19 vaccine and the second group was vaccinated with combination of HS and OMPs subunit vaccines beside vaccination with Br. abortus strain RB51 (S/C). From first day post vaccination to 60 days, saliva, vaginal discharge, fecal and milk samples were collected and examined for the presence of the vaccinal strains. Also, blood samples were collected from vaccinated animals and the serum tested serologically using RBPT, MAT and ELISA. In addition, cell mediated immune response was evaluated using Brucellin test. The results revealed that no vaccinal strains was detected in the different body secretions and the humoral immune response of vaccinated cows reached its peak at the $4^{\text {th }}$ week post vaccination then decreased gradually and disappeared at the end of the $10^{\text {th }}$ week. Also, cell mediated immune response revealed that cows vaccinated with the combination of HS and OMPs subunit vaccine combined with conjunctival vaccination with $\mathrm{Br}$. abortus strain 19 vaccine showed remarkable increase in the cell mediated immune response in comparison with in cattle vaccinated with the same combination beside subcutaneous vaccination with Br. abortus strain RB51.
\end{abstract}

Keywords: bovine brucellosis, humoral immune response, Brucellin test

$$
\text { (http://www.bvmj.bu.edu.eg) }
$$

(BVMJ-29(1): 26-31, 2015)

\section{INTRODUCTION}

$\mathrm{B}$ rucellosis constitutes a major health and economy problem in many parts of the world. The disease causes storm of abortion, retained placenta, orchitis and arthritis in the infected animals (Lamees, 2003, Mariano et al., 2012). In Egypt, it is difficult to differentiate whether the causative agent of bovine brucellosis was due to $\mathrm{Br}$. abortus or $\mathrm{Br}$. melitensis as they both can cause the disease (Abdel Moghney et al., 2012). Crude Brucella membrane protein induced a strong significant level of protection in mice, challenged with $\mathrm{Br}$. melitensis virulent strain $16 \mathrm{M}$ and the level of protection was similar to that induced by $\mathrm{Br}$. melitensis Rev.1 vaccine. A genetic vaccine based on the OMP31 gene can elicit a strong cellular immune response and crude OMPs is a good candidate for use in future studies of vaccination against Bovine Brucellosis (Doosti et al., 2009). Vaccination with hot saline extract (HS) of $\mathrm{Br}$. ovis conferred good protection against $\mathrm{Br}$. ovis but protection was greatly enhanced by the incorporation of QS- 21 or other adjuvants. Jimenez de Bagues et al. (1994) adjuvanated HS vaccine afforded protection against challenge with Br. ovis as good as or better than that provided by attenuated Brucella melitensis vaccine strain Rev.1. Therefore, this study was conducted to evaluate $\mathrm{Br}$. abortus vaccine and subunit 
vaccine of Br. melitensis in vaccination of cows against bovine brucellosis.

\section{MATERIAL AND METHODS}

\subsection{Brucella strains:}

Br. melitensis strain H38: A virulent strain was kindly obtained from USDA, Nation Veterinary Laboratories (NSVL), Ames, Iowa, 50010, USA. Br. abortus strain 19: A vaccinal strain was kindly obtained from seed strain (obtained from Nation Veterinary Laboratories (NSVL), 1800 Dayton Avenue, Ames, Iowa, 50010, USA. Br. abortus strain RB51: It was obtained from Professional Biological Company, 4950 Yorj Street, Denver, Colorado 80216.

\subsection{Experimental Design and vaccination program:}

Ten female local breed cows were obtained from Animal Production Institute, Dokki, Giza. All cows under experiment were proved to be free from internal, external and blood parasites. Also, the sera of these animals were screened for the presence of antibodies against Brucella and proved to be free. Six of them were pregnant and parturated then was lactating during the experiment time.

\subsection{Samples:}

Serum samples: From the first week of vaccination till 10 weeks post vaccination blood samples were collected from all vaccinated animals in sterile MacCartney bottles. Fecal, vaginal and milk samples: They were collected from $1^{\text {st }}$ day post vaccination until 60 days and examined for possible shedding of the vaccinal strain according to Alton et al. (1988).

\subsection{Rose Bengal Plate Test and Microagglutination Test:}

These were carried out according to Morgan et al. (1969) and Brown et al. (1981) for the evaluation humoral immune response against the vaccines used.

\subsection{ELISA test:}

It was carried out according to Alton et al. (1988) for the evaluation of the humoral immune response.

\subsection{Delayed hypersensitivity test:}

It was carried out according to Alton et al. (1988) for evaluation of the cell mediated immunity against the vaccines.

\section{RESULTS}

Table (1): Results of brucellin test in cows vaccinated with a combination of HS and OMPs subunit vaccine combined with conjunctival vaccination with $4 \times 10^{9} \mathrm{CFU}$ strain 19 vaccine

\begin{tabular}{|c|c|c|c|c|c|c|}
\hline \multirow{2}{*}{ Animal No. } & & \multicolumn{5}{|c|}{ Observation time (Hours) post inoculation of brucellin } \\
\hline & & Pre-inoculation & 4 & 24 & 48 & 72 \\
\hline 1 & & $2.3 \mathrm{~mm}$ & No change & $2.9 \mathrm{~mm}$ & $6.8 \mathrm{~mm}$ & $4.1 \mathrm{~mm}$ \\
\hline 2 & & $2.0 \mathrm{~mm}$ & No change & $2.4 \mathrm{~mm}$ & $6.4 \mathrm{~mm}$ & $3.9 \mathrm{~mm}$ \\
\hline 3 & & $2.2 \mathrm{~mm}$ & No change & $2.9 \mathrm{~mm}$ & $6.7 \mathrm{~mm}$ & $3.5 \mathrm{~mm}$ \\
\hline $\begin{array}{l}\text { Control } \\
\text { vaccinated }\end{array}$ & non- & $2.0 \mathrm{~mm}$ & No change & $2.0 \mathrm{~mm}$ & $2.0 \mathrm{~mm}$ & $2.0 \mathrm{~mm}$ \\
\hline
\end{tabular}

Table (2): Results of brucellin test in cows vaccinated with a combination of HS and OMPs subunit vaccines combined with $4 \times 10^{9} \mathrm{CFU}$ RB51 strain vaccine injected subcutaneously

\begin{tabular}{|c|c|c|c|c|c|c|}
\hline \multirow{2}{*}{ Animal No. } & & \multicolumn{5}{|c|}{ Observation time (Hours) post inoculation of brucellin } \\
\hline & & Pre-inoculation & 4 & 24 & 48 & 72 \\
\hline 1 & & $2.2 \mathrm{~mm}$ & $2.4 \mathrm{~mm}$ & $3.2 \mathrm{~mm}$ & $5.8 \mathrm{~mm}$ & $3.6 \mathrm{~mm}$ \\
\hline 2 & & $2.0 \mathrm{~mm}$ & $2.2 \mathrm{~mm}$ & $2.9 \mathrm{~mm}$ & $5.8 \mathrm{~mm}$ & $3.3 \mathrm{~mm}$ \\
\hline 3 & & $2.1 \mathrm{~mm}$ & $2.1 \mathrm{~mm}$ & $2.9 \mathrm{~mm}$ & $5.6 \mathrm{~mm}$ & $3.3 \mathrm{~mm}$ \\
\hline $\begin{array}{l}\text { Control } \\
\text { vaccinated }\end{array}$ & non- & $2.2 \mathrm{~mm}$ & $2.2 \mathrm{~mm}$ & $2.2 \mathrm{~mm}$ & $2.2 \mathrm{~mm}$ & $2.2 \mathrm{~mm}$ \\
\hline
\end{tabular}


Table (3): Results of RBPT and MAT in cows vaccinated with a combination of HS and OMPs subunit vaccine combined with $4 \times 10^{9} \mathrm{CFU}$ of strain 19 vaccine inoculated conjunctively

\begin{tabular}{lllll}
\hline $\begin{array}{l}\text { Weeks post } \\
\text { vaccination }\end{array}$ & $\begin{array}{l}\text { RBPT } \\
\%\end{array}$ & No. $*$ & Reaction ** & MAT \\
\hline 1 & $100 \%$ & $5(5)$ & ++ & 83 \\
2 & $100 \%$ & $5(5)$ & +++ & 215 \\
3 & $100 \%$ & $5(5)$ & +++ & 293 \\
4 & $100 \%$ & $5(5)$ & +++ & 302 \\
5 & $80 \%$ & $4(5)$ & ++ & 254 \\
6 & $80 \%$ & $4(5)$ & ++ & 192 \\
7 & $80 \%$ & $4(5)$ & + & 107 \\
8 & $60 \%$ & $3(5)$ & + & 86 \\
9 & $40 \%$ & $2(5)$ & + & 56 \\
10 & $20 \%$ & $1(5)$ & - ve & 20 \\
\hline
\end{tabular}

* Number of positive animals. ** Mean degree of the total serum samples test.

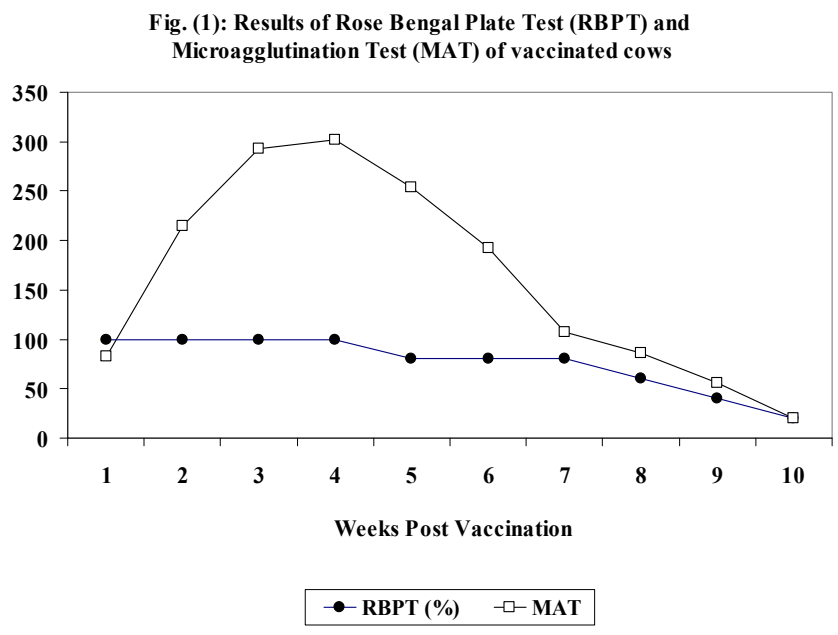

Table (4): Results of ELISA test in cows vaccinated with a combination of HS and OMPs subunit vaccines combined with $4 \times 10^{9} \mathrm{CFU}$ strain 19 vaccine inoculated conjunctivally

\begin{tabular}{|c|c|c|c|c|c|c|c|}
\hline \multirow{2}{*}{$\begin{array}{l}\text { Weeks post } \\
\text { vaccination }\end{array}$} & \multicolumn{5}{|c|}{ Optical density of samples } & \multirow{2}{*}{$\begin{array}{l}\text { Mean } \\
\text { OD }\end{array}$} & \multirow{2}{*}{$\begin{array}{l}\text { ELISA } \\
\text { Unit }\end{array}$} \\
\hline & 1 & 2 & 3 & 4 & 5 & & \\
\hline 1 & 0.756 & 0.783 & 0.719 & 0.625 & 0.879 & 0.752 & 25.3 \\
\hline 2 & 0.9645 & 0.8770 & 1.0205 & 1.1725 & 1.1995 & 1.047 & 57.6 \\
\hline 3 & 1.3260 & 1.0385 & 1.0515 & 1.2535 & 1.1295 & 1.158 & 69.7 \\
\hline 4 & 1.6005 & 1.5675 & 1.3945 & 1.6125 & 1.6080 & 1.557 & 113.4 \\
\hline 5 & 1.430 & 1.441 & 1.364 & 1.394 & 1.344 & 1.396 & 95.81 \\
\hline 6 & 1.198 & 1.151 & 1.158 & 1.153 & 1.239 & 1.180 & 72.2 \\
\hline 7 & 0.868 & 0.862 & 0.943 & 0.952 & 0.991 & 0.923 & 44.1 \\
\hline 8 & 0.7465 & 0.6485 & 0.6915 & 0.8775 & 0.7250 & 0.738 & 23.7 \\
\hline 9 & 0.632 & 0.696 & 0.641 & 0.622 & 0.695 & 0.657 & 14.9 \\
\hline 10 & 0.607 & 0.636 & 0.600 & 0.664 & 0.621 & 0.626 & 11.5 \\
\hline
\end{tabular}

N.B. +ve ELISA unit $>20$ 


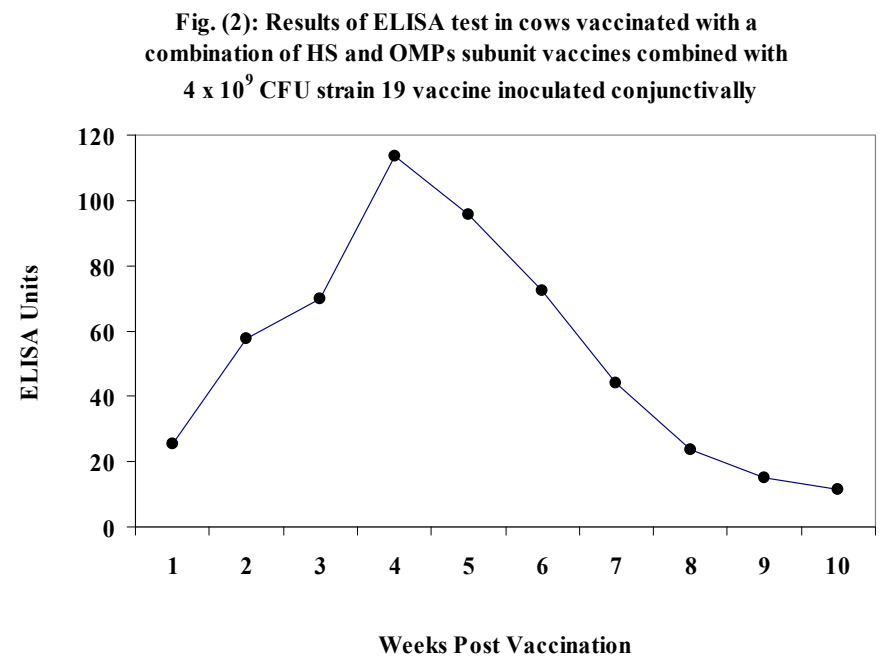

Table (5): Results of Rose Bengal Plate Test (RBPT) and microagglutination of cows vaccinated with combination of HS and crude OMP subunit vaccines combined with subcutaneous vaccination with $4 \times 10^{10} \mathrm{CFU}$ of RB51 strain vaccine

\begin{tabular}{lllll}
\hline $\begin{array}{l}\text { Weeks } \\
\text { vaccination }\end{array}$ & $\begin{array}{l}\text { Rost } \\
\%\end{array}$ & No. & Reaction ** & MAT \\
\hline 1 & $100 \%$ & $5(5)$ & + & 62 \\
2 & $100 \%$ & $5(5)$ & ++ & 117 \\
3 & $100 \%$ & $5(5)$ & ++ & 206 \\
4 & $100 \%$ & $5(5)$ & +++ & 287 \\
5 & $80 \%$ & $4(5)$ & ++ & 232 \\
6 & $80 \%$ & $4(5)$ & + & 186 \\
7 & $80 \%$ & $4(5)$ & + & 97 \\
8 & $60 \%$ & $3(5)$ & + & 53 \\
9 & $20 \%$ & $1(5)$ & $-v e$ & 17 \\
10 & $20 \%$ & $1(5)$ & $-v e$ & 17 \\
\hline
\end{tabular}

Fig. (3): Results of Rose Bengal Plate Test (RBPT) and microagglutination of cows vaccinated with combination of HS and

crude OMP subunit vaccines combined with subcutaneous vaccination with $4 \times 10^{9} \mathrm{CFU}$ of RB51 strain vaccine

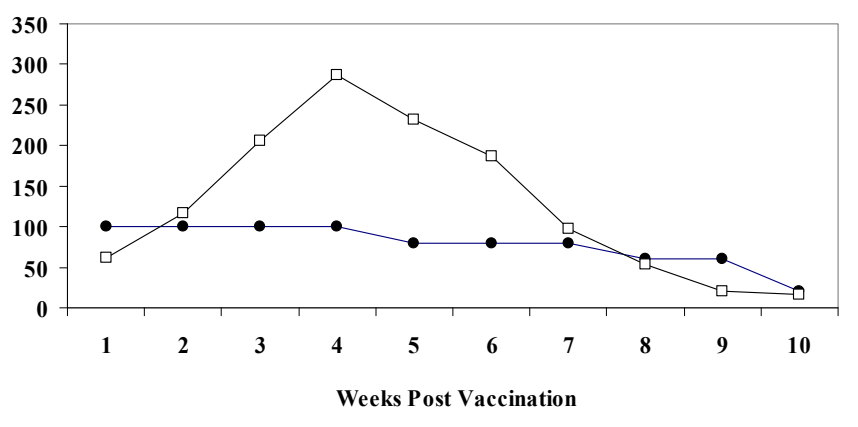

$\bullet-$ RBPT (\%) $\neg-$ MAT 
Table (6): Results of ELISA test in cows vaccinated with combination of HS and crude OMP subunit vaccines combined with subcutaneous vaccination with 4 X $10^{9}$ CFU RB51 strain vaccine

\begin{tabular}{|c|c|c|c|c|c|c|c|}
\hline \multirow{2}{*}{$\begin{array}{l}\text { Weeks post } \\
\text { vaccination }\end{array}$} & \multicolumn{5}{|c|}{ Optical density of samples } & \multirow{2}{*}{$\begin{array}{l}\text { Mean } \\
\text { OD }\end{array}$} & \multirow{2}{*}{$\begin{array}{l}\text { ELISA } \\
\text { Unit }\end{array}$} \\
\hline & 1 & 2 & 3 & 4 & 5 & & \\
\hline 1 & 0.437 & 0.362 & 0.344 & 0.420 & 0.404 & 0.393 & 14.9 \\
\hline 2 & 0.456 & 0.427 & 0.440 & 0.488 & 0.509 & 0.464 & 26.6 \\
\hline 3 & 0.622 & 0.644 & 0.612 & 0.577 & 0.543 & 0.600 & 48.9 \\
\hline 4 & 0.678 & 0.654 & 0.704 & 0.712 & 0.796 & 0.709 & 66.7 \\
\hline 5 & 0.621 & 0.537 & 0.621 & 0.648 & 0.695 & 0.613 & 51.0 \\
\hline 6 & 0.592 & 0.528 & 0.521 & 0.614 & 0.628 & 0.577 & 45.1 \\
\hline 7 & 0.537 & 0.495 & 0.488 & 0.587 & 0.604 & 0.542 & 39.3 \\
\hline 8 & 0.451 & 0.407 & 0.517 & 0.551 & 0.588 & 0.503 & 33.0 \\
\hline 9 & 0.498 & 0.418 & 0.377 & 0.422 & 0.472 & 0.437 & 22.1 \\
\hline 10 & 0.456 & 0.404 & 0.462 & 0.314 & 0.407 & 0.409 & 17.5 \\
\hline
\end{tabular}

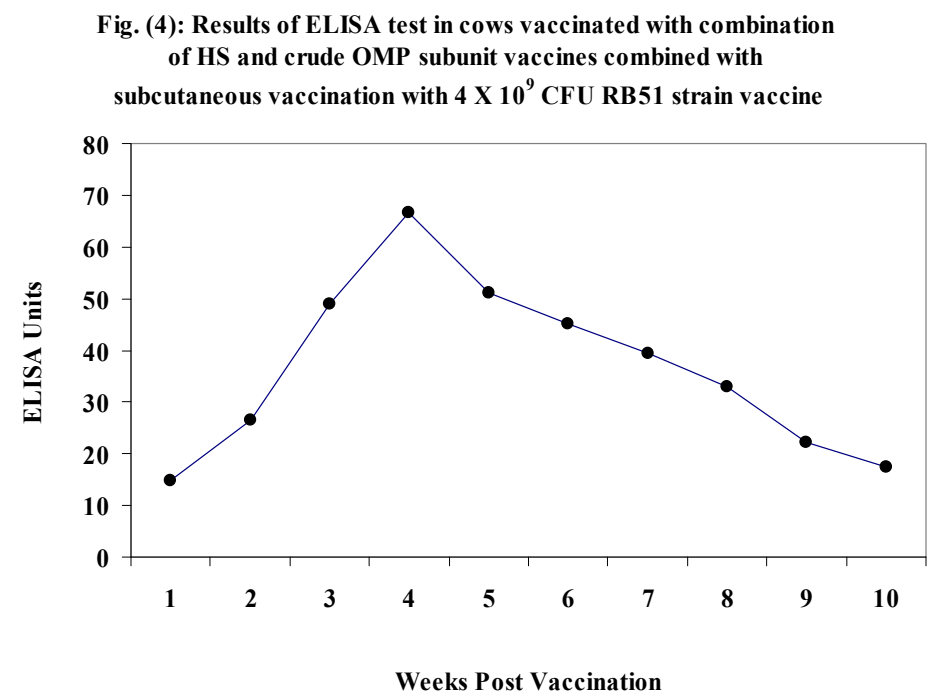

\section{DISCUSSION}

The present study was aimed to find out the best type of brucella vaccination program which can be used for control of bovine brucellosis in Egypt without or with minimum disadvantage. To achieve this aim, two groups of cows were vaccinated with a combination of oily adjuvanted HS and OMPs subunit vaccine combined with either conjunctival vaccination with $\mathrm{Br}$. abortus strain 19 vaccine in one group or subcutaneous vaccination with $\mathrm{Br}$. abortus strain RB51 in the second group. The shedding of the different vaccinal strains in the body secretions or the milk of vaccinated cows revealed that no vaccinal strains were detected. The obtained results agreed with results obtained previously (Nicoletti, 1984, Lim, 1990, Perez et al. 1995, Olsen et al. 1995, Samartina et al., 2000, Lamees, 2003). The evaluation of the humoral immune response of vaccinated cows was conducted by application of the serological tests on the serum samples as RBPT, MAT and ELISA. The results indicated that all the vaccines used in this study produced antibody responses which began from $1^{\text {st }}$ week post vaccination reaching their peak on the $4^{\text {th }}$ week and decreased gradually and nearly disappeared within 10 weeks (Tables 3, 4, 5, 6) and (Fig. $1,2,3)$. These results are similar to that obtained by Fensterbank et al. (1982), OIE (1996), Olsen et al. (1998), Perez et al. (1995), Alavi Shoushtari and Zeinali 
(1995), Nicoletti (1984) and Lim (1990). The results of Brucellin illustrated in Tables $(1,2)$ showed increased in skin thickness, and reached their maximum level at 48 hours after $\mathrm{i} / \mathrm{d}$ inoculation of Brucellin. These results agreed with that of Ottosen and Plum (1955), Bercovich and Muskens (1999) and Saegerman et al. (1999).

\section{REFERENCES}

Abdel Moghney, A.F., M.R. Khoudair, M.A. Montasser, Amany A. Sallam and Lamees H. Tantawy 2012. "Effect of echinaecae on the immune response of vaccinated G. pigs with Brucella vaccine". Egypt. J. Agric. Res., 90(1).

Alavi-Shoushtari, S.M., Zeinali, A. 1995. Response of female lambs to Rev1 (brucellosis) vaccines. Preventive Vet. Med., 21 (4): 289-297.

Alton, G.G., Jones, L.M., Angus, R.D. and Varger, J.M. 1988. Techniques for brucellosis laboratory. Institute National de le Recherche Agronomique (INRN), 147 Rue due L'Universite, 75007, Paris.

Bercovich, Z. and Muskens, J.A.M. 1999. The efficacy of the skin delayed hypersensitivity using a brucellin prepared from a mucoid strain of Brucella abortus to detect brucellosis. Vet. J., 157 (1):61-67.

Brown, S.L., Klin, G.C. and Jones, W.L. 1981. Safranin-O stained antigen microoagglutination test for detection of Brucella antibodies. J. Clin. Micro., 13:398-400.

Doosti, A., Ghasemi-Dehkardi, P., GholamReza Javadi, S. Sardari, and Shokrgozan, M.A. 2009. DNA vaccine encoding the OMP31 gene of Br. melitensis induces protective immunity in $\mathrm{BALB} / \mathrm{C}$ mice. Res. J. Biol. Sci., 4 (1):126-131.

Fensterbank, R., Pardon, P. and Marly, J. 1982. Efficacy of Brucella melitensis Rev-1 vaccine against Br. ovis. Ann. Rech. Vet., 13 (2): 185-190.

Jimenez de Bagues, M.P., Elzer, P.H., Jones, S.M., Blasco, J.M., Enright, F.M., Schurig, G.G. and Winter, A.J. 1994. Vaccination with $\mathrm{Br}$. abortus rough mutant RB51 protects $\mathrm{BALB} / \mathrm{C}$ mice against virulent strains of $\mathrm{Br}$. abortus, $\mathrm{Br}$. melitensis and Br. ovis. Inf. Immun., 62(11):4990-4996.

Lamees A. El-Tantawi 2003. Some studies on Brucellosis in sheep. Ph.D. Thesis in Vet. Science (Infectious Diseases), Faculty of Veterinary Medicine, Cairo University.

Lim, A.A. 1990. A test for differential diagnosis between vaccinated cattle, those with brucellosis. Vet. Inst., I/2: 27-30 (Vet. Bull., 62, Abstract 5988).

Mariano, C. Ferrero, Carlos, A. Fossati, Martin Rumbo and Pablo, C. Baldi 2012. "Brucella invasion of human intestinal epithelial cell elicil a weak proinflammatory response but a significant CCL20 secretion". FEMS Immunology and Medical Microbiology, 66(1): 45-57.

Morgan, W.J.B., Mackinnon, D.J. and Cullen, G.A. 1969. The Rose Bengal plate agglutination test in the diagnosis of brucellosis. Vet. Rec., 85: 636.

Nicoletti, P. 1984. The epidemiology of brucellosis in animals. Dev. Biol. Stand., 56: 623-628.

OIE 1996. Manual of Standards for Diagnostic tests, vaccine.

Olsen, S.C., Stevens, M.G., Palmer, M. and Cheville, N.F. 1995. Efficacy of Brucella abortus strain RB51 to protect cattle against brucellosis. Proceed. Annual Meet. US Animal Hlth. Assoc., 99:108110.

Olsen, S.C., Jensen, A.E., Palmer, M.V. and Stevens, M. 1998. Evaluation of serological response, clearance from lymphatic organs after vaccination. Amer. J. Vet. Res., 59(4):410-415.

Perez et al. 1995. Vacunacion de ovejas lactantes con Rev-1 por via conjunctival ITEA, 16:339-541.

Saegerman, C., Vo, T.K.O., Waele, L.De, Gilson, D., Bastin, A., Dubray, G., Flanagan, P., Limet, J.N., Letsson, J.J. and Godfroid, J. 1999. Diagnosis of bovine brucellosis by skin test. Conditions for the test and evaluation of its performance. Vet. Rec., 145 (8):214218 .

Samartino, L; Gall, D.; Gregoret, R. and Nielsen, K. 1999. Validation of ELISA for the diagnosis of bovine brucellosis. Vet. Microbiology 70(3/4):193-200. 